\title{
Noskov V.I. \\ The civil suit in criminal proceedings In Russian Federation
}

Kuban state agricultural university

(Russia, Krasnodar)

doi: $10.18411 / s r-10-04-2019-16$

idsp: sciencerussia-10-04-2019-16

\section{Abstract}

With adoption of the Code of criminal procedure the institute of the civil suit in criminal proceedings underwent a number of changes and amendments. In many respects they are caused by the purpose of the legislator to provide protection of interests of the civil claimant and civil defendant and also expansion of their procedural laws as participants of criminal proceedings. Accurate determination of legal status of the civil claimant and defendant, establishment of a uniform order of presentation and consideration of the civil suit in criminal proceedings will allow to avoid violations of the criminal procedure legislation and to provide timely and effective protection of persons, to property or the non-material benefits of which harm is done.

In article the procedural status of the civil claimant, civil defendants and from legal representatives in criminal proceedings in the Russian Federation is considered.

Keywords: civil claimant, civil defendant, criminal process

Relevance of a subject of a research. In the Constitution of the Russian Federation of people, his rights and freedoms are announced by the supreme value and is proclaimed that recognition, observance and protection of the rights and freedoms of the person and citizen are an obligation of the state. Performance of this duty in the sphere of law-enforcement activity is carried out, in particular, and means of criminal proceedings.

Directed to restoration violated by crime of the rights and the interests of the personality and the state, criminal proceedings act as the instrument of assignment on certain persons criminal, and are frequent as well civil responsibility for the actions made by them. By compensation of the harm done by crime it is necessary to face need of realization of civil responsibility on considerable number of criminal cases. Therefore during criminal procedure activity the important importance is gained by providing and protection of property interests of natural and legal entities, besides equally as those which suffered damage from crime and demand its compensation, and the persons obliged to compensate the harm done by this act under the law.

The purpose and research problems consist in studying at the monographic level of all complex of the questions relating to the civil defendant and, as a result of it, in justification of the conclusions allowing to make suggestions for improvement of the current legislation and practice of activity of bodies of investigation and vessels. Achievement of this purpose is provided with the solution of the following tasks: disclosure of the procedural and legal nature and essence of this participant of process; consideration of the criminal procedure status of the civil defendant; the analysis of norms of various industries of Russian law (civil, civil and procedural, family, labor) in a varying degree connected with legal regulation of participation of the civil defendant in criminal proceedings; characteristic of all natural and legal entities acting as the civil defendant; a research of the law-enforcement activity having the contents participation of the civil defendant in each stage of criminal proceedings, definition at the same time of a degree of activity of use of the rights by it; justification of suggestions for improvement of the legislation and practice of its use.

Methodological and theoretical basis of work. The methodology of a dissertation research was based on the principles of dialectic materialism as general method of knowledge. Works on criminal procedure, civil law and also other industries of the right are studied and critically comprehended. 
Compensation of this harm within criminal proceedings is carried out first of all by means of the civil suit according to which production is characterized by its complex structure, large volume of actions and certain features of a procedural form in comparison with procedural and procedural rules of assignment on a person of criminal liability. In particular, in relation to subject structure the specified features find the expression in such participants as the civil claimant and the civil defendant who are as well participants of criminal proceedings in general. Told confirms importance of deep studying of questions of the civil suit and the related criminal procedure activity. The civil suit in criminal case is the requirement about compensation of the property harm (or compensations of moral harm) done by crime, stated in criminal proceedings by the person to which such harm is done and also his representative or the prosecutor, shown to the defendant or the person bearing property responsibility for actions of the defendant under the law, resolved together with criminal case, and is equal - the requirement about compensation of moral harm when causing by crime of moral, physical or property harm.

At the same time the civil suit about compensation of moral harm is possible along with the claim of the victim of crime of the person for compensation to it the property harm done by crime.

The civil suit in protection of interests of minors, the persons recognized as incapacitated or it is limited capable in the order established by the civil procedural legislation, persons who for other reasons cannot protect the rights and legitimate interests it can be shown by their lawful representatives or the prosecutor, and in protection of interests of the state - the prosecutor.

The civil suit in criminal proceedings - an important procedural security measure of property rights and the interests of citizens and legal entities, compensations of moral harm. According to such value of the civil suit court, the prosecutor, the investigator, the investigator, are obliged to explain to interested persons their right to make the civil suit in criminal proceedings and also to petition for taking measures of providing the claim.

Measures for ensuring compensation for the civil suit can be taken both in pre-judicial stages of process, and in stages of preparation for court session and judicial proceedings.

Proof according to the civil suit (establishment whether property harm in what size whether moral suffering is inflicted by crime) is also an obligation of the called public authorities is caused to this person directly by crime and is included into a proof subject of criminal case.

Advantages of the civil suit in criminal proceedings: the claimant is exempted from payment of the state fee; the state accuser has the help in the face of the civil claimant; the duality is excluded, there is no need to twice call the citizens involved in the sphere of criminal proceedings for participation them in proof as circumstances of crime, and in permission of the civil suit; simultaneous consideration and permission of criminal case and the civil suit provides the fullest, comprehensive and objective investigation of circumstances of incident.

The subject of the civil suit in criminal proceedings makes material damage which can be expressed in money which causing - a direct consequence of the committed crime. As criminal proceedings only the actual damage caused by crime, the straight losses which are in a direct causal relationship with illegal act is subject to compensation. The question of compensation of indirect losses (including the missed benefit) is taken out for a framework of criminal proceedings and is solved as civil legal proceedings.

As material damage it is understood: the damage caused as a result of loss of property; the damage which resulted from a mutilation, disability; the expenses connected with treatment and drugs; the means spent for hospital treatment; the expenses connected with keeping of the persons who are dependent on the dead; expenses on burial.

Subject of the civil suit in criminal proceedings is also moral harm done by crime. Moral harm - the moral or physical suffering inflicted by the crime encroaching on the non-material benefits belonging to the citizen from the birth and by the law: life, health, dignity of the personality, business reputation, personal privacy, personal and family secret. So, at initiation of legal proceedings under the Article 139 of the Criminal code of the Russian Federation Criminal code (disturbance of inviolability of the dwelling), Article 173 of the Criminal code (false 
business), Article 213 of the Criminal code and many other presentation of the civil suit for the purpose of compensation of the moral harm done by crime is possible.

Property and moral harm is compensated, as a rule, by the defendant. The duty of indemnification can be also assigned by the law to the person, not done harm. Can act as such person: parents, adoptive parents, trustees of minors aged from 14 till 18 flyings (Article 1074 of the Civil code of the Russian federation (Civil code); educational, medical institutions, institutions of social protection of the population and other similar institutions which by the law are the child's trustee aged from 14 till 18 flyings (Article 1074 of the Civil code; parents of minors aged from 14 till 18 flyings, deprived of the parental rights (Article 1075 of the Civil code; trustees and the organizations obliged to exercise supervision of incapacitated citizens (Article 1076 of the Civil code; able-bodied the spouse, parents, full age children who are in common living with the person, prichinvshy harm who could not understand values of the actions or the Criminal code, to direct them owing to a mental disorder if they knew about this frustration, but did not ask about recognition of this person incapacitated (Part 3 Article 1078 of the Civil code; owners of sources of the increased danger (vehicles), if do not prove that harm arose owing to force majeure or intention of the victim (Article 1079 of the Civil code.

Proof of the civil suit in criminal proceedings is made by the rules established in the criminal procedure law. Jurisdiction of the civil suit is defined by jurisdiction of criminal case in which it is shown.

Presentation of the civil suit is possible both the victim, and his representative from the moment of initiation of legal proceedings before the end of judicial examination at trial of this criminal case in court of first instance. At presentation of the civil suit the civil claimant is exempted from payment of the state fee. Presentation of the civil suit does not demand existence in business of the defendant, i.e. is admissible also in cases when on business the person who has to be attracted as the defendant is not identified yet. In the presence of data that harm to the victim is done by joint criminal acts of several persons the civil suit can be made to each of them. Requirement about indemnification imposed to all persons which in common did harm is possible. The prosecutor makes the civil suit in the cases, the Criminal code specified in Part 3 Article 44 of the Code of criminal procedure of the Russian Federation (Code of criminal procedure).

The civil claimant has the right to refuse the claim made to them. The investigator, the investigator, court before accepting such refusal, have to explain to the civil claimant of a consequence of refusal of the civil suit. Such rule corresponds to the content of the principle of protection of the rights and freedoms of the person and citizen in criminal proceedings (Part 1 Article 11 of the Code of criminal procedure).

The refusal of the civil suit involves cessation of production in the claim. By results of judicial proceedings the court takes out one of the following decisions:

1) satisfies the civil suit in whole or in part at removal of a conviction. At the same time he is obliged to resolve questions in whose advantage and in what size the civil suit is subject to satisfaction (Paragraph 10 Part 1 Article 299 of the Code of criminal procedure). The claim is considered satisfied, first, at the resolution of a conviction (with appointment, without assignment of punishment, with release from punishment) and, secondly, only at establishment of full structure of the bases (prerequisites) of the size of requirements. In cases of satisfaction of the claim in whole or in part the court can establish and the Criminal code to specify in a sentence term for voluntary execution of a sentence regarding the civil suit. Compulsory execution is made in the order established by the legislation on enforcement proceeding.

2) dismisses the civil suit (Part 2 Article 306 of the Code of criminal procedure) at the resolution of the verdict of not guilty, pronouncement of the resolution or definition on the termination of criminal case on the bases provided by Paragraph 1 Part 1 of Article 24 and Paragraph 1 Part 1 of Article 27 of the Code of criminal procedure. At the resolution of a conviction the court has the right to dismiss the civil suit if the lack of harm is established or the causal relationship between actions of the convict and the come harm is not proved; 
3) leaves the civil suit without consideration at the resolution of the verdict of not guilty, pronouncement of the resolution or definition on the termination of criminal case on the bases provided by Paragraphs 2-6 of Part 1 of Article 24, 25, Paragraphs 3-5 of Part 1 of Article 27, Article 28 of the Code of criminal procedure. The court has the right to leave the civil suit without consideration at absence of the civil claimant on court session (Part 3 Article 250 of the Code of criminal procedure). Leaving of the civil suit by court without consideration does not interfere with the subsequent its presentation and consideration as civil legal proceedings.

By consideration of the civil suit made in criminal case, the bases, conditions, volume and a way of indemnification are defined according to standards of civil, labor and other law. In the cases provided by the law the international agreements and norms of foreign law are applied.

A civil claimant is the natural or legal entity who imposed requirement about compensation of property harm in the presence of the bases to believe that this harm is done to it directly by crime.

The decision on recognition by the civil claimant is made out by definition of court or the judge's ruling, the investigator, the investigator. Along with the announcement of the resolution on recognition of the person by the civil claimant the official who made this decision is obliged to notify on all made decisions relating to the civil suit stated to them and to hand to the civil claimant of the copy of the documents which are making out them (Paragraph 13 Part 4 Article 44 of the Code of criminal procedure); to inform of the complaints and representations which arrived on business (Paragraph 19 Part 4 Article 44 of the Code of criminal procedure).

As the civil claimant the citizen participates personally or along with the representative, and legal entities - through the representative. As infliction of harm by crime attracts recognition of the citizen by the victim (Article 42 of the Code of criminal procedure), the citizen - the civil claimant has to be recognized also as the victim. In affairs of private prosecution in this case he will be also a private accuser. In the Criminal code, in such situation the citizen will have the rights of the civil claimant, the victim and the private accuser (which in many respects coincide).

The civil suit can be made after initiation of legal proceedings and before the end of judicial examination at trial of this criminal case in court of first instance.

The civil claimant participates in charge function implementation. He is given practically the same rights, as the victim (Part 4 Article 44 of the Code of criminal procedure). The law limits to the civil claimant access to case papers at the end of investigation only to that volume of documents which are related to the made claim (Paragraph 12 Part 4 Article 44 of the Code of criminal procedure). The refusal of the civil suit can be declared by the civil claimant at any moment of criminal proceedings, but before removal of court to the consultative room for the resolution of a sentence (Part 5 Article 44 of the Code of criminal procedure).

The civil defendant - natural or legal entity which according to the Civil code bears responsibility for the harm done by crime, attracted as the civil defendant with the resolution of the investigator, investigator, judge or definition of court (Part 1 Article 54 of the Code of criminal procedure).

Attraction as the civil defendant is carried out when the duty of compensation of the harm done by crime is assigned by the law to the person who did not do harm, but bears responsibility for the harm done to defendants.

In case of presentation of the civil suit and in the presence for this purpose the bases the investigator, the investigator in pre-judicial criminal proceedings are obliged to issue the decree on attraction as the civil defendant. In judicial proceedings the judge or court according to the petition of the party of charge issue the relevant decree (definition) expressing will of the party about involvement of the person as the civil defendant.

Involvement of the person as the civil defendant has to be followed by explanation to it its procedural laws.

The civil defendant has the right: to know essence of claim requirements and a circumstance on which they are based. For this purpose the civil defendant has the right to get acquainted with the civil suit made in criminal case; to object to the made civil suit. For this 
purpose it has the right to give, for example, the corresponding evidences, to produce the evidence; to offer explanations and indications on the substance of the civil suit.

The civil defendant uses some other the rights similar to the rights of the victim, civil claimant (Paragraph 4-15 Part 2 of Article 54 of the Code of criminal procedure).

The civil defendant is obliged:1) to be on calls of the investigator, investigator or in and court; 2) not to disclose data of preliminary investigation under the threat of criminal prosecution on Article 310 of the Criminal code.

On the basis of Part 1 of Article 55 of the Code of criminal procedure lawyers can be representatives of the civil defendant, and representatives of the civil defendant who is the legal entity - also the other persons competent according to the Civil code to represent its interests. By definition of court or the judge's ruling, the investigator, the investigator as the representative of the civil defendant one of his close relatives or the other person for whose admission the civil defendant petitions can be also allowed.

The representative of the civil defendant has the same rights, as the civil defendant (Part 2 Article 54 of the Code of criminal procedure). Personal participation in criminal proceedings of the civil defendant does not deprive of him the right to have the representative. In this case both that, and another has the right to have the rights provided Parts 2 of Article 54 of the Code of criminal procedure.

The civil claimant has the right to refuse the claim made to them. The investigator, the investigator, court before accepting such refusal, have to explain to the civil claimant of a consequence of refusal of the civil suit. Such rule corresponds to the content of the principle of protection of the rights and freedoms of the person and citizen in criminal proceedings (Part 1 of Article 11 of the Code of criminal procedure).

The refusal of the civil suit involves cessation of production in the claim. By results of judicial proceedings the court takes out one of the following decisions:

1) satisfies the civil suit in whole or in part at removal of a conviction. At the same time he is obliged to resolve questions in whose advantage and in what size the civil suit is subject to satisfaction (Paragraph 10 Part 1 Article 299 of the Code of criminal procedure). The claim is considered satisfied, first, at the resolution of a conviction (with appointment, without assignment of punishment, with release from punishment) and, secondly, only at establishment of full structure of the bases (prerequisites) of the size of requirements. In cases of satisfaction of the claim in whole or in part the court can establish and the Criminal code to specify in a sentence term for voluntary execution of a sentence regarding the civil suit. Compulsory execution is made in the order established by the legislation on enforcement proceeding.

2) dismisses the civil suit (Part 2 Article 306 of the Code of criminal procedure) at the resolution of the verdict of not guilty, pronouncement of the resolution or definition on the termination of criminal case on the bases provided Paragraph 1 Part 1 Article 24 and Paragraph 1 Part 1 Article 27 of the Code of criminal procedure. At the resolution of a conviction the court has the right to dismiss the civil suit if the lack of harm is established or the causal relationship between actions of the convict and the come harm is not proved;

3) leaves the civil suit without consideration at the resolution of the verdict of not guilty, pronouncement of the resolution or definition on the termination of criminal case on the bases provided Paragraph 2-6 Part 1 Article 24, 25, Paragraph 3-5 Part 1 Article 27, Article 28 of the Code of criminal procedure. The court has the right to leave the civil suit without consideration at absence of the civil claimant on court session (Part 3 Article 250 of the Code of criminal procedure). Leaving of the civil suit by court without consideration does not interfere with the subsequent its presentation and consideration as civil legal proceedings.

Having summed up the result of the aforesaid, it should be noted that the institute of the civil suit in criminal proceedings needs to be kept. This institute makes an integral part of the Russian criminal proceedings, and its liquidation would mean deterioration in a legal status of persons to which crimes did property or moral harm. 
1. Constitution of the Russian Federation [Text]: ofitsa. text. - M.: PRIOR, 2001.

2. The civil code of the Russian Federation [Text] / part one of November 30, 1994 No. 51-FZ, Part second of January 26, 1996 No. 14-FZ, Part third of November 26, 2001 No. 146-FZ and Part fourth of December 18, 2006 No. 230-FZ (as of December 25, 2008) - M.: Omega-L publishing house, 2008.

3. The Code of Civil Procedure of the Russian Federation [Text] / of November 14, 2002 No. 138-FZ with changes and additions of December 4, 2007 - M.: Omega-L publishing house, 2008.

4. Code of Criminal Procedure of the Russian Federation. [Text]: ofitsa. text: (as of January 15, 2009). - M.: Omega-L publishing house, 2009.

5. Criminal Code of the Russian Federation [Text]: ofitsa. text: (as of February 10, 2008). - M.: Omega-L publishing house, 2008.

6. Alexandrov O.V. Institut of the civil suit in the Russian law of criminal procedure: formation prerequisites//Current problems of the theory and history of the right and the state at the present stage: Collection of scientific works of the VII international scientific and practical conference. - Kostroma: KGTU, 2010. - Page 214-219

7. Antonov I., Berova D., Gorlenko V. Procedural function of maintenance of the civil suit and protection against him and her development during pre-judicial criminal cases production//Arbitration and civil process. - M.: Lawyer, 2009, No. 3. - Page 17-21

8. Novikova V.V. The civil suit in criminal case//the Practical zakonoiskusstvo. - Stavropol: Practical zakonoiskusstvo, 2009, No. 1 (4). - Page 111-114

9. P.N., Krasnov K.A. honey buzzard. About a problem of indemnification by the victim at a stage of preliminary investigation//Criminal proceedings. 2009. No. 4. Page 30 - 33. 